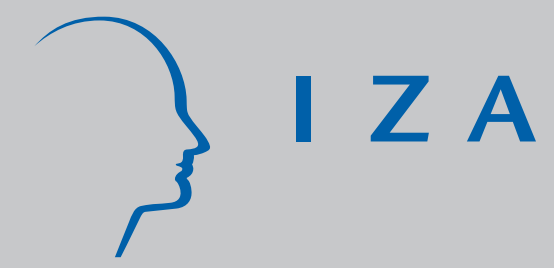

IZA DP No. 422

The Long Awaited Reform of the German Works Constitution Act

J ohn T. Addison

Lutz Bellmann

Claus Schnabel

J oachim Wagner

February 2002 


\title{
The Long Awaited Reform of the German Works Constitution Act
}

\author{
John T. Addison \\ Department of Economics, Moore School of Business, University of South \\ Carolina, Free University of Bozen-Bolzano, Italy and IZA, Bonn \\ Lutz Bellmann \\ Institute for Employment Research (IAB), Nürnberg and IZA, Bonn
}

Claus Schnabel

Friedrich Alexander University, Erlangen-Nürnberg

Joachim Wagner

University of Lüneburg, HWWA and IZA, Bonn

Discussion Paper No. 422

February 2002

\author{
IZA \\ P.O. Box 7240 \\ D-53072 Bonn \\ Germany \\ Tel.: +49-228-3894-0 \\ Fax: +49-228-3894-210 \\ Email: iza@iza.org
}

This Discussion Paper is issued within the framework of IZA's research area Evaluation of Labor Market Policies and Projects. Any opinions expressed here are those of the author(s) and not those of the institute. Research disseminated by IZA may include views on policy, but the institute itself takes no institutional policy positions.

The Institute for the Study of Labor (IZA) in Bonn is a local and virtual international research center and a place of communication between science, politics and business. IZA is an independent, nonprofit limited liability company (Gesellschaft mit beschränkter Haftung) supported by the Deutsche Post AG. The center is associated with the University of Bonn and offers a stimulating research environment through its research networks, research support, and visitors and doctoral programs. IZA engages in (i) original and internationally competitive research in all fields of labor economics, (ii) development of policy concepts, and (iii) dissemination of research results and concepts to the interested public. The current research program deals with (1) mobility and flexibility of labor, (2) internationalization of labor markets, (3) the welfare state and labor markets, (4) labor markets in transition countries, (5) the future of labor, (6) evaluation of labor market policies and projects and (7) general labor economics.

IZA Discussion Papers often represent preliminary work and are circulated to encourage discussion. Citation of such a paper should account for its provisional character. A revised version may be available on the IZA website (www.iza.org) or directly from the author. 
IZA Discussion Paper No. 422

February 2002

\section{ABSTRACT}

\section{The Long Awaited Reform of the German Works Constitution Act}

German law guaranteeing works councils is not a datum. The thrust of legislation has changed significantly on a number of occasions since 1920. The most recent legal change in the form of the Works Constitution Reform Act marks a controversial swing in favor of works council formation and authority. The present paper evaluates the new legislation from an economic perspective. We link the crucial terms of the new legislation to extant empirical evidence on the incidence of works councils, the availability of alternative employee involvement mechanisms, and the impact of the institution on performance by establishment size. Given the limitations of the evidence, which are shown to have relaxed the constraints on legislative innovation, we also offer some new empirical findings based on a matched-plants approach, using a nationally representative sample of establishments. This empirical strategy in principle offers improved estimates of the effects of works councils on establishment performance. Although the results of this exercise differ somewhat from earlier analyses, they provide little support for the recent legislative changes.

JEL Classification: J24, J53, J58, K31

Keywords: $\quad$ works council legislation, codetermination, employee-involvement mechanisms, establishment performance, matched-plants approach

John T. Addison

Department of Economics

Moore School of Business

University of South Carolina

Columbia, SC 29208

U.S.A.

Tel.: +1-803-777-4608

Fax: +1-803-777-6876

Email: ecceaddi@darla.badm.sc.edu 


\section{Introduction}

For many years the German system of codetermination has been regarded as exemplary, in much the same manner as that country's system of apprenticeship training. (In what follows, we restrict our attention to the codetermination at the workplace, Betriebliche Mitbestimmung, and not that at the enterprise level through worker representation on company boards.) Indeed, with the fall in union density in many nations, the German system of (indirect) worker participation has enjoyed further popularity as a potential solution to the problem of sub-optimal worker involvement hinted at by the facts of union decline. Even the United States has flirted with works councils on

the German pattern. ${ }^{1}$ More generally, of course, the European Union (EU) has often used the German institution as something of a template in designing various of its measures seeking to increase worker participation, the most recent example being its draft legislation on national systems for informing and consulting employees. ${ }^{2}$

If foreign observers have seen much to admire in the works council apparatus, their German counterparts have expressed concern with its operation. These concerns were rehearsed before a special Codetermination Commission (Kommission Mitbestimmung), set up in 1996 by the Bertelsmann and Hans Böckler Foundations. The Commission reported in 1998. Its main conclusions were that codetermination at the establishment level was under-provided by the market despite the mandatory (but not automatic) status of works councils under law, and that changes needed to be made to the structure and mode of functioning of codetermination so as to defend its economic performance. The deliberations of the Commission, coupled with strong demands from the union movement for reform, provided the basis for a new Works Constitution Act which entered into law in July 2001 and which materially extended the authority of the works council.

The present paper examines the key 'codetermination-deficit' assumption of the Commission and evaluates the implications of the legislation from an economic perspective. We do not address other than in passing the issue of equity, which we would equate with notions of industrial democracy. To be sure, and as we shall see, other observers would see issues of economic performance as subordinate to such equity considerations but we would justify our efficiency emphasis on two grounds. First, research has paid insufficient attention to the effects of works councils on performance. This has led to a de-emphasis of economic considerations on the part of policy makers. Second, equity considerations cannot be divorced from efficiency 
issues, especially in circumstances where 'insider' power may be an issue and where there exist alternative mechanisms for engaging the workforce. Given the admitted deficiencies of the existing literature - most notably as regards causality and works council endogeneity - we also seek to inform the debate on what works councils do by offering a new empirical analysis of the effects of codetermination on establishment performance.

The outline of the paper is as follows. First, we identify the immediate background to the latest revision of the Works Constitution Act. Second, we identify the principal changes introduced under the new law. Third, we address the perceived costs and benefits of these changes as expressed in the political debate leading up to the legislation. We then contextualize matters by linking the legislative changes to the extant empirical evidence along three dimensions: the frequency and distribution of works councils; the availability of alternative participative mechanisms; and the impact of works councils on economic performance by establishment size. Since the empirical evidence is unsettled, we next seek to advance the economic debate on works councils by examining the effects of changes in works council status across otherwise matched samples of establishments. A concluding section draws together the threads of our developing argument and new empirical strategy.

\section{The Evolution of Workplace Codetermination}

The German lower chamber, the Bundestag, passed the law reforming the pre-existing Works Constitution Act (Betriebsverfassungsgesetz) on June 22, 2001. The new Works Constitution Reform Act (BetrVerf-Reformgesetz) was approved by the upper house, the Bundesrat, on July 13, 2001. It became effective on July 28, 2001, the day after its announcement in the Federal Law Bulletin (Bundesgesetzblatt). ${ }^{3}$

The new law represents another directional change in German law. The history of codetermination at the workplace dates back to World War I with the formation of workers' committees (Arbeiterausschüsse) to mobilize union support for the war effort. Works councils per se were formally established shortly thereafter under the first Works Councils Law (Betriebsrätegesetz) of 1920. Works councils and unions were abolished/absorbed during the National Socialist era, and only reemerged during the occupation years - first on an ad hoc basis and then under laws passed by individual Länder. The procedures obtaining in the various regions of the country were consolidated under national legislation in 1952. Because the new law 
gave fewer codetermination rights than the various state provisions that they replaced, and because works councils were now to be formally independent from as opposed to being subordinate to unions as under the 1920 legislation, the 1952 Act is often depicted as a defeat for labor. Further changes in the law occurred in 1972 some three years after the election of a coalition government of Social Democrats and Free Democrats. The new Works Constitution Act widened and strengthened the rights of works councils. Additionally, it improved the access of unions to the workplace and promoted collaboration between works councils and unions. ${ }^{4}$

The immediate backdrop to the most recent changes in the law $^{5}$ is provided by the deliberations of the Codetermination Commission and the debate pursuant to its conclusions. Among other things, the Commission was set up to evaluate experience with the workings of the 1972 Act. It comprised high-ranking scientific, economic, union and political representatives, and was supported by expert reports from the academic community. ${ }^{6}$ The Commission's final report, entitled "Co-Determination and New Business Cultures - Conclusion and Perspectives," was presented in May 1998 (Kommission Mitbestimmung, 1998). ${ }^{7}$ It reasoned that it cannot be decided from either theory or the [extant] empirical evidence whether the overall effect of works councils is positive or negative: "in the real world codetermination as an institution generates both efficiency-reducing misallocation and efficiency-raising productivity and cooperative effects. The net impact of these parallel and simultaneous partial effects cannot be determined $a$ priori" (English translation, para. 27; Kommission Mitbestimmung, 1998, paras. 5.22-5.23, pp. 64-65). Although the Commission does not offer any concrete proposals for the reform of existing legislation, it emphasizes the presence of a large and growing codetermination-free zone (see English translation, para. 19; Kommission Mitbestimmung, 1998, pp. 50-51),warning that: "A gradual erosion [of the institution of codetermination] cannot, in the public interest, be left to the vagaries of the market" (Kommission Mitbestimmung, 1998, para. 6.16, p. 76).

Contemporaneous with the publication of the final report of the Codetermination Commission, the Federation of German Unions presented its own draft proposals for a new Works Constitution Act (see Deutscher Gewerkschaftsbund, 1998). Among the more important of its demands were the following:

- a reduction in the size threshold (from 5 to 3 permanent employees) that has to met before a works council may be set up and in the number of this total (from 3 to 1) that meet the criterion of being eligible to be works councilors; 
- registration of all enterprises without works councils in an accessible public register;

- $\quad$ simplified election procedures in small enterprises with less than 100 employees;

- $\quad$ an increase in the number of works councilors;

- a reduction in the size threshold (from 300 to 200 employees) at which firms are required to make provision for full-time (i.e. paid) works councilors, as well as a general increase in their number;

- a extension of the works council's codetermination rights in a number of respects (e.g. codetermination rights when teamworking is introduced and subsequently in its execution).

In short, à la Gompers, the union federation sought more works councils (especially in small firms), more works councilors, more paid full-time works councilors (in large firms), and more co-determination rights for works councils.

The position of the ruling Social Democrat-Green coalition government (elected in the Fall of 1998) was to be accommodating. On October 20, 1998, it announced its intention to reform and strengthen codetermination at establishment level, ${ }^{8}$ but it was not until the end of 2000 that an informal set of reform measures was issued. These (unpublished) proposals were drafted by the Minister of Labor and Social Order, Walter Riester, and quickly circulated outside the participating governmental institutions. Not surprisingly, in meeting many of the union demands, the reform agenda occasioned much public controversy. The critics included not only employers and economists but also the Economics Minister, Werner Mueller. For a brief interlude it appeared that there would be open conflict in the cabinet between the two ministers. After protracted negotiations, however, a revised set of reforms was agreed in cabinet on February 14, 2001, and draft legislation was duly issued by the Federal Government at the beginning of April.

The government's Bill and the counter proposals of the two opposition parties - the CDU/CSU and the FDP $^{9}$ - were debated in the Committee for Labor and Social Order May 14, $2001 .^{10}$ A slightly modified version of the Bill was passed by the lower chamber on June 22, 2001, and approved by the upper house on July 13, 2001. ${ }^{11}$ The Act became effective on July 28 , 2001. 


\section{The Innovations}

The Works Constitution Reform Act makes changes to a number of existing regulations and includes some new rules of its own. Although detailed investigation of the full array of the amendments and innovations is beyond the scope of this essay (but again see fn. 11), the key innovations are as follows: ${ }^{12}$

(Tables 1 and 2 near here)

- the structure of the works council becomes more diverse than heretofore. In enterprises with more than one establishment, works councils can be formed across some or all of the constituent establishments, while for enterprises that are organized along 'lines of business' works councils may follow the self-same structure;

- the creation of a works council is facilitated in establishments employing between 5 and 50 employees through a simplified voting procedure. This procedure can also be extended to establishments with 51 to 100 employees. Further, the 3 employees who are required to set in motion the procedure for initiating a works council receive time-limited protection against dismissal;

- temporary workers may participate in works council elections if they have been employed for more than three months at the establishment;

- the functions of the works council are widened, and the protection of its members is strengthened. The thresholds used to determine the size of the works council are lowered. Table 1 contrasts the numbers of works councilors for various size classes of establishment under the old and new legislation. For example, the number of works councilors in an establishment with 150 employees is raised from 5 to 7 and in an establishment with 500 employees from 9 to 11;

- employers are required to make provision for a full-time works councilor in establishments with 200 or more employees, instead of 300 as before. The thresholds for additional full-time councilors are also lowered. Table 2 compares the number of such paid full-time works councilors by establishment employment size threshold under old and new legislation;

- the employer has to furnish the works council at his own expense with modern information and communication technology, and the works council is entitled to consult with competent employees and to form working groups;

- the influence of the works council in matters of employment protection and the training of the workforce is strengthened. This includes the possibility of enforcing training measures that benefit employees whose qualifications are rendered obsolete. Also, the works council has codetermination rights in the execution of teamwork; 
- the influence of any single employee in the codetermination process is strengthened by his or her being able to require the works council to debate a particular issue when supported by at least five percent of the workforce;

- codetermination on environmental protection issues is explicitly recognized as a function of the works council;

- gender equality is facilitated by the requirement that the minority gender at the establishment be represented on the works council at least in proportion to its employment share. Further, the works council has the right to suggest plans for the promotion of women and make these the subject of human resource planning wherein the employer has to consult the works council;

- youth and trainee representation is increased. In establishments with more than 100 employees, such groups have the right to form their own committees;

- the works council is equipped with formal means to avoid racism and xenophobia in the workplace via its power to withhold consent in matters of the engagement and transfer of personnel in special cases.

Each of the above points can be analyzed from an economic perspective. In what follows, we restrict our attention to the two most controversial issues that attach to the legislation: the likely increase in the number of works councils and in their complements of full-time members.

\section{Some German Controversies over the Costs and Benefits of Works Councils}

Although there are no official statistics on the distribution of works councils by establishment size, the empirical evidence suggests that their coverage is modest in small- and medium-sized workplaces (see section V). Indeed, it was the growing importance of such establishments, especially in the service sector, that provided the basis of the Codetermination Commission's diagnosis of a "codetermination-free zone."

For the Federal government this perceived participation gap was central to its reform of the Works Constitution Act. Nevertheless, it should be borne in mind that the size threshold for works council formation is only 5 employees (of whom 3 must be 'eligible' to be works councilors) and that employees can independently decide whether or not they want a works council. In the past no less than today, once the procedure was initiated by employees the election of a works council was to all intents and purposes automatic, outside of those instances where the employer sought actively to avoid its formation (an illegal activity and as such sanctioned under law). 
From a positive economics standpoint, the absence of a works council in many medium-sized establishments represents a problem only in so far as this produces efficiency losses. Theoretically, the net outcome is unclear because of the two-faces of the works council - by analogy with the union institution (see Freeman and Medoff, 1984). As a vehicle of collective voice, the works council collects information on the preferences of workers. It thus allows workers to voice their discontent about workplace conditions rather than quitting. This in turn allows management to design a wage and human resource policy that can improve morale, lower labor turnover, and improve productivity. The improved exchange of information and the consultation and codetermination rights of the works council can serve to reduce inefficiencies, and by engaging the workforce on a constructive and long-term basis shape the future development of the establishment in a manner conducive to improvements in welfare. On the other hand, the rights ceded to the works council allow it to postpone or alter profit-motivated decisions and to transfer part of the surplus to labor. If such actions also influence the investment decisions of the plant there can be dynamic as well as static inefficiencies.

The legal powers of the works council are both strengths and weaknesses. In the first place, legal obligations can complement market forces (specifically, reputation effects) to reinforce the credibility of the employer's commitment to take workers' interests into account. As a result there may be improved disclosure by the worker side and attendant welfare gains. Secondly, however, the other side of the coin is redistribution of the surplus in favor of labor. Within limits, rent seeking may be compatible with an increase in the joint surplus but this time be logically rejected by management (Freeman and Lazear, 1995). The key is therefore to provide some way of limiting redistribution while preserving the potential efficiency gains from cooperation. Here, the German law again enters the picture because of the peace obligation and the dual industrial relations system in which the works council machinery is embedded (wherein wage negotiations between works councils and management are not authorized under law). This is clearly not the end of the story - because, as noted earlier, the legal authority or competence of the works council in a wide range of other matters affords numerous opportunities to extract pecuniary and non-pecuniary concessions - but it does establish the crucially important German dimension of the broader debate over works councils.

Apart from the aim of increasing works council penetration among small- and medium-sized enterprises, it was a stated goal of the Federal government to increase the number of councilors 
and to improve works council operation. To the latter end, as we have seen, the new regulations provide that works councils are to be equipped with modern information and communication technology and improved opportunities for employing consultants in circumstances of workplace change (in establishments with more than 100 employees). In addition, of course, greater provision is made for the part-time release of works councilors and for more paid full-time works councilors (starting at 200 employees as compared with 300 previously).

Each measure to a smaller or greater degree implies an increase in the costs of operating a works council. The costs have exclusively to be borne by employers. Mid-size establishments are likely to be most affected. For example, an establishment employing 200 employees now has for the first time to bear the costs of one paid full-time works councilor. This development alone represents an increase in its wage bill of one half of one percent.

Whether or not these and other sources of increased costs can be offset by higher operating efficiency and revenues is ultimately an empirical question. In the next section, we summarize the extant evidence on works councils, flag the unsettled issues in that empirical literature, and identify some estimation problems. As will become apparent, there is a patent disconnect between the scientific evidence and the strong positions taken in the political debate surrounding the reform of the Works Constitution Act.

The federal government assuredly recognized that increased costs were implied by increases in the number, size, and authority of works councils. The prologue to the draft legislation of November 2000 contains the statement: "Democracy is not cost neutral. This principle also applies to democracy at the workplace and to the resulting system of establishment-level codetermination. The benefit of an operational system of codetermination outweighs the additional expenses." ${ }^{13}$ Why this is expected to be the case is expanded upon in the justification for the legislation: "The additional costs to the establishment have to be set against the advantages from worker participation. Codetermination establishes trust. This trust facilitates flexible and process-open forms of cooperation and thus, for example, lowers transaction costs in the establishment. In addition, employees who know that their interests are represented in the firm and works councils that are able to incorporate these interests into the decision making process can increase the productivity of the undertaking and thence the competitiveness of the German economy (see Report of the Codetermination Commission, p. 64f., paras. 22-23)."14 
This line of official reasoning, which draws on collective voice notions, is remarkable in two respects. First, the corresponding (i.e. cited) statements of the Codetermination Commission are much more guarded. Indeed, it is explicitly conceded that the net effect of two forces efficiency-retarding resource misallocation and efficiency-generating productivity and cooperation - cannot be determined a priori (Kommission Mitbestimmung, 1998, ch. 5, para. 22, p. 64). Second, the Commission's report stresses just how little empirical evidence was available at the time of its writing (Kommission Mitbestimmung, 1998, ch. 5, para. 14, p. 61)

The counter-proposals of the opposition parties (CDU/CSU and FDP) focused upon immediate cost issues. No reference is made to future profitability or for that matter to costbenefit appraisal. The representatives of the CDU/CSU argued as follows: "The decrease in size thresholds is going to sharply increase the number of works councilors, especially in small and medium-sized enterprises, as well as the number of paid full-time works councilors. This places an unreasonable burden on mid-size enterprises thereby damaging their competitiveness, raising costs and jeopardizing employment." ${ }^{15}$ Accordingly, it was proposed that works councils should be set up in plants with less than 21 employees only if a majority of employees voted in favor. ${ }^{16}$ This demand is echoed in the submission of the representatives of the FDP, who further argued that the number of works councilors should fall below the levels set under the previous legislation and that the threshold size for paid full-time councilors should be raised and their number reduced. ${ }^{17}$ They concluded that: "The financing of codetermination in small- and midsize establishments will lead to a significant increase in costs and in some cases threaten their very existence." 18

The controversy over the federal government's draft proposals is also reflected in the submissions of other interest groups and institutions at the public hearing before the Committee for Labor and Social Order of the German Lower House on May 14, 2001. ${ }^{19}$ Perceptions of the likely costs and benefits of the draft proposals differ considerably. For example, the German Federation of Christian Trade Unions (Christlicher Gewerkschaftsbund Deutschlands) took the position that any benefit-cost analysis was wrong headed: "The costs and benefits cannot be posed in this way because there is no alternative other than the participation of responsible employees." 20 For its part, the German Catholic Worker Movement (Bundesverband der Katholischen Arbeitnehmerbewegung Deutschlands) asserted that the costs and benefits would likely be a wash: "Democracy and humanization at the workplace cannot be free of charge. The 
price paid for codetermination will be offset by more reliable labor relations, peace in the workplace and in society - the well known advantages of Germany as a business location." ${ }^{21}$ The Confederation of German Employers' Associations (Bundesvereinigung der Deutschen Arbeitgeberverbände) argued that only the costs side could be estimated: "Codetermination is ... a considerable cost-factor for the German economy. Reliable estimates of the costs of codetermination to undertakings exceed DM 10 billion while the benefits cannot be calculated. The issue of whether the benefits are primarily the result of codetermination or could equally be observed in establishments without codetermination cannot be answered on the basis of available evidence." 22 The American Chamber of Commerce stressed that: "The proposed draft expands existing codetermination bodies, creates new bodies, creates additional bureaucracy in the establishment, slows down many decision processes, and most importantly generates additional costs. This reform bill acts like a deterrent, especially for foreign investors." ${ }^{23}$ Various representatives of medium-sized enterprises were more alarmist. Thus, for example, the Federation of Building-Cleaning Trades (Bundesinnungsverband des GebäudereinigerHandwerks) argues: "The draft proposals ... threaten the very survival of small- and mediumsized enterprises in the industry. In particular, the costs associated with the growth in paid fulltime works councilors and extremely higher training costs are unsustainable." ${ }^{24}$

It is remarkable that these and other publicly-stated positions make reference to costs and benefits without any recourse to the German economic/econometric data. The notable exceptions are the contributions of the Society of Self-Employed Businesses (Arbeitsgemeinschaft Selbständiger Unternehmer), the Cologne Institute for Business Research (Institut der deutschen Wirtschaft Köln), and the Institute for Labor Law and Industrial Relations in the European Community (Institut für Arbeitsrecht und Arbeitsbeziehungen in der Europäischen Gemeinschaft). ${ }^{25}$ The latter do make reference to the studies reviewed in the next section. In what follows, we comment on the consequences of a greater number of works councils, more works councilors, more paid works councilors, and expanded works council rights from the perspective of that literature.

\section{Works Council Presence and Impact: A Survey of the Extant Evidence}

Although research on works councils is limited there have been some major advances in recent years with the availability of new data sets. (The early literature was based on very small 
samples of firms that were investigated and reinvestigated - for surveys of this literature, see Addison, Kraft and Wagner, 1993; Addison, Schnabel, and Wagner, 2000a). Here we propose to largely limit our review to studies using larger, more representative data sets because these enable us more effectively to address the key themes raised by the preceding discussion: works council coverage; the existence of other forms of worker involvement; and works council impact along various dimensions of economic performance by firm size.

Our starting point is works council incidence and coverage. As we have seen, the Codetermination Commission noted the (sharply increasing) presence of a "codetermination free zone" wherein there was neither board level nor works council codetermination. It reported that this sector encompassed some 60.5 (45 percent) percent of all private sector (private and public sector) employees in the mid-1990s (Kommission Mitbestimmung, 1998, p. 53). Despite the absence of official data, information from several sources confirm that large numbers of establishments and employees in the private sector do not have works councils. ${ }^{26}$

(Table 3 near here)

In Table 3 we provide the most up-to-date and representative information on works council incidence and coverage by establishment size, using current data from the IAB (Institut für Arbeitsmarkt- und Berufsforschung der Bundesanstalt für Arbeit) Establishment Panel, described in section VI below. The data reveal the familiar pattern of spotty works council incidence among smaller establishments and correspondingly low employment coverage. But the proportion of workplaces with works councils reaches a little over 50 percent (as does the share of employment represented by works council establishments) for plants with 51-100 employees. And works council incidence and coverage continues to increase monotonically with establishment size, though less so for eastern than for western Germany. In overall terms, works councils are encountered in just 16.3 percent of all German establishments, even if the share of employment accounted for by works council establishments -53 percent - is sharply higher than that.

The direct association between works council coverage and establishment size can reasonably be linked to the potential influence of the works council. After all, participation rights increase with employment size not only with respect to number of (unpaid and full-time) works councilors, noted earlier, but also regarding the right to detailed information on personnel movements and notification of reductions in force ( $>20$ employees), the establishment of an 
economics committee (>100 employees), and the involvement of the works council in developing guidelines for criteria in personnel selection and movements ( $>1,000$ employees). There are of course a variety of other employment size-related factors that may be at work here, including the public-goods aspects of many working conditions, monitoring considerations, internal labor market structuring and, less positively, worker dissatisfaction associated with routinized, regimented work settings.

A multivariate regression analysis of the determinants of works council presence has been provided by Addison, Schnabel, and Wagner (1997), using data from the first wave of the Hannover Firm Panel. ${ }^{27}$ In addition to firm size (and its square), the authors control for branch plant status (to capture any demonstration effect a mother plant might have on its affiliate) and plant age (to capture a tradition of collective bargaining). Apart from these 'structural' variables, the authors include several variables intended to capture a 'taste for collective representation' on the part of the workforce, namely, the percentage of blue-collar, female, part-time, and shift workers. Also, to test for some associations suggested by the earlier empirical literature, they deploy a number of 'participation' variables - in the form of dummies for teamworking and profit sharing - as well as the percentage of workers covered by incentive pay.

The authors present simple probit estimates for their total sample of industrial establishments in Lower Saxony and for a subsample of plants with 10-249 employees (within which size interval works council incidence falls between the extremes of miniscule and full coverage). Across both samples there is a consistent relation between the structural variables and work council presence. That is, the probability of observing a works council increases with establishment size (albeit at a decreasing rate) and with the age of the plant, and is also greater if the establishment is a branch plant. As far as the taste for collective representation variables are concerned, these all behave in the anticipated manner but only the share of female employees is statistically significant across both samples. The effect of the participation variables is rather interesting. There is, for example, the suggestion that teamworking is associated with a reduced probability of observing a works council. (The same is true for employee profit sharing but in this case the coefficient estimate(s) is poorly determined.) This result is consistent with the argument of FitzRoy and Kraft $(1985,1987)$ that better managers can devise efficient communication and motivational alternatives to the impedimenta of a bureaucratized, timeconsuming works council apparatus. Both arguments are expanded upon below. 
In a very recent analysis of two waves of the Hannover Firm Panel, Hübler and Jirjahn (2001) essentially confirm all (but one) of these results, including the negative association between teamworking and works council presence. Their point estimates are generally more precisely estimated, although they do not present estimates for other than the total sample of establishments, use 15 rather than 30 industry dummies, and omit the profit-sharing variable. In addition, they report that works councils are more likely in circumstances where employers provide further training ${ }^{28}$ and where there are flexible working time arrangements, as might be explained by the specific role reserved for the works council in each area. On the other hand, they find that works councils are less likely to be encountered in plants making use of the newest production technology. In general their results from this univariate probit exercise are replicated using a bivariate probit approach, accommodating simultaneous coverage or otherwise by a collective bargaining agreement. We will return to the issue of collective bargaining coverage when considering the economic impact of works councils, only noting here that data on union membership is too imprecise in this data set to allow serious investigation of the link between this other conventional measure of union influence and works council incidence.

The bottom line is that the incidence of works councils seems to be fairly well explained by organizational factors and elements associated with the specific functions of the works council. There is nothing to contradict the Commission's claim that the codetermination-free zone is largely made up of comparatively small establishments. However, the principal extension of the results - that the practice of teamworking is negatively associated with the likelihood of observing a works council - points to the existence of other methods of employee involvement that may be a substitute for representative participation.

We now take up the latter point, using data from the first wave of the Hannover Firm Panel (as noted below, the teamwork question in the IAB panel is not usable). The relevant question of the underlying survey inquires of the manager respondent whether or not blue-collar workers in the establishment are deployed in teams. Since the question defines teams to be "groups characterized by expanded involvement in decision making and increased responsibility," it provides a useful basis for measuring the participation of the (manual) workforce. The survey reveals that the incidence of teamworking is more extensive than codetermination per se. Thus, approximately 48 percent of all establishments in the sample employing more than 60 percent of all employees have teamworking. By contrast only 21 percent of all workplaces have a works 
council, although these establishments account for a somewhat higher share (73 percent) of employment. Teamwork is strongly entrenched in small and medium-sized workplaces: more than 40 percent of small establishments (with 5-20 employees) and 60 percent of medium-sized establishments (21-100 employees) practice teamworking. Assuredly, there is also a zone characterized by neither teamwork nor codetermination - 43 percent of all establishments employing 12 percent of all employees - but the fact remains that 43 (61) percent of all small (medium-sized) establishments without a works council do have teamwork. On this metric, therefore, codetermination-free should not be equated with participation-free.

But we can go further than this to examine information provision and consultation. Question 67 of the survey asks managers to identify which of six "sources of information" are used when large investments in the production process are planned, and also to stipulate the frequency of their use ("normal," "sometimes," and "never"). One such source is "discussions with employees who will work directly with the investment." Considering only those situations where discussions with the workforce are the rule, the survey reveals that almost 60 percent of establishments regularly consult the workforce - a little more than one-half in the case of small establishments and more than two-thirds for medium-sized plants. Expressed differently, only one-third of all establishments (employing just one-tenth of all employees) has neither a works council nor consultative arrangements of this kind.

Finally, the Hannover Firm Panel also contains information on participation through the mechanism of profit sharing. Unlike direct participation through teamwork (and consultation on investment), this indirect form of participation is much less common than representative participation through the works council. Just 11 percent of all establishments in the sample, employing one-quarter of all employees, have profit-sharing schemes for the workforce (excluding executives). This proportion is much lower in the smaller establishments than in their larger counterparts. The share of plants with profit sharing is just 8.5 percent for small establishments and 16 percent for medium-sized plants, as compared with 21 percent for workplaces with more than 100 employees. The representation of profit sharing among establishments without a works council is admittedly lower than in their counterparts with works councils but the more obvious result is the limited amount of indirect participation in Germany, especially when compared with Anglo-Saxon countries.

(Table 4 near here) 
Table 4 gives more detail on these associations. At one level, there is again support for the Commission's characterization of a codetermination-free zone in Germany - almost all small establishments and half of medium-sized plants subject to the (old) law have no works council and as a result no formal vehicle for codetermination. But if this point seems unassailable, we have also seen that the appellation 'codetermination-free' should not be equated with 'participation-free' since there seemingly exist other mechanisms for engaging the workforce. Although such mechanisms may also be under-provided by the market, ${ }^{29}$ their presence at least calls into question the efficacy of a (government) solution that focuses mechanically on representative participation. To address the issue of whether the existing literature supports formalization along these lines, we turn in conclusion to analyses of the effect of works councils on the economic performance of the establishment.

The early literature documenting works council effect on establishment performance is scarcely supportive of the German mandate. Practically every study fails to uncover any beneficial effects of the institution. For total factor productivity, studies by FitzRoy and Kraft (1987) and Addison, Kraft, and Wagner (1993) point either to negative or statistically insignificant effects of the works council. As regards establishment profitability, strongly negative effects are reported by FitzRoy and Kraft (1985), and weakly negative effects by Addison, Kraft and Wagner (1993) and Addison and Wagner (1997). As far as investment is concerned, the evidence is patchy: only one study examines works council impact on a measure of physical investment (capital investment/capital stock) and obtains a negative coefficient estimate for the works council dummy variable that is statistically significant at conventional levels (Addison, Kraft and Wagner, 1993). However, this result does not generally carry over to investments in intangible capital (e.g. Schnabel and Wagner, 1994; Addison and Wagner, 1997). ${ }^{30}$ Finally, in a very different labor turnover study that attempts to peer inside the black box of productivity augmenting mechanisms, Kraft (1986) reports that individual voice seemingly dominates collective voice (proxied by works council presence) as a mechanism for lowering quit rates.

But if the early evidence was generally pessimistic - sometimes profoundly so - as regards works council impact, the problems of small sample size dog the estimates. Each study considers small samples of firms/workplaces (never exceeding 74 units) and cover different sectors and time intervals. Accordingly, there is a very real issue as to the representativeness of their 
findings. Biases associated with the likely nonrandom distribution of works councils also cast a longer shadow in small sample, cross-section analyses of this type. ${ }^{31}$ Moreover, the studies typically do not venture beyond the deployment of a works council dummy variable to gauge the impact of the institution although we know from industrial relations studies that the institution is unlikely to be a datum. ${ }^{32}$

If this were the end of the story, one could perhaps understand the thoroughly agnostic stance of the Commission - if not the more general inference in political debate and public discourse leading up to the new Act that the economic effects of the German participative model were benign. But it is not the end of the story because results from a much larger data set - the Hannover Firm Panel - had become available well before the Codetermination Commission issued its report and the Government its draft proposals for reform of the Works Constitution Act. Although problems of statistical inference continue to attach to the new estimates of works council impact from this data set (see below), they do raise some disturbing issues that might have been expected to have informed the public debate.

The hallmark of the Hannover Panel studies is their attempt to differentiate works council impact across establishments of different sizes. This is in part an attempt to deal with the criticism attaching to the use of a simple works council dummy variable in most of the earlier studies. But it is less a response to presumed works council idiosyncracy (suggested by the industrial relations literature) than to the suggestion that the costs of operating a works council might be much higher for smaller establishments and the benefits correspondingly smaller because of the availability of informal (and other) participative mechanisms. (By the same token, since informal mechanisms are not available to the same degree larger establishments, proproductive works council effects might be observed on the grounds that in the absence of a mandate firms might be compelled to introduce something like them but yet face problems in setting them up in the absence of a mandate because of credibility problems or fear of rentseeking behavior.) In addition, to the extent that works council authority and bureaucratization increase with rising establishment size, there are grounds for expecting differences in impact at certain employment thresholds. For the very smallest firms with 5-20 employees the constraint of a single works councilor may pose few difficulties, whereas in firms with 21-100 employees the growth in the number of councilors ( 3 up to 50 employees, 5 thereafter) and the requirement that the works council receive detailed information on personnel movements (plus documentation) as 
well as notification of reductions in force may be a real constraint. Of course, the rights of the works council increase further as establishment size climbs above 100 employees, beginning with the establishment of an economics committee ( $>100$ employees), continuing with the appointment of full-time works councilors (at 300 [now 200] employees), through to the development of guidelines for criteria in personnel selection and movements $(>1,000$ employees). Indeed, the biggest extension of codetermination authority may accompany parity worker representation on company boards, although the complication here is that practically all establishments in the sample have works councils well before this particular size threshold $(>2,000$ employees) is reached.

(Table 5 near here)

There are, then, grounds for examining differences in works council effect by establishment size. Table 5 provides summary results from the first wave of the Hannover Firm Panel on associations between works council presence and a variety of outcome indicators for three employment size intervals. The regressions from which these estimates of works council effect are derived contain a large number of control variables, and are available from the authors on request. Published variants are contained in Addison, Schnabel, and Wagner (1998, 1999, 2000b, 2001)..$^{33}$

The key variables of interest in the earlier literature were labor productivity, profitability, and innovation. The table supplements information on these indicators with results for wages and turnover measures. What do we find? Beginning with labor productivity (measured as value added per worker), there is no indication that productivity is higher in either small or mediumsized plants with works councils. The former sample is 98 percent works council free and 48 percent of the latter sample have no works council. Pro-productive effects are restricted to establishments with more than 100 employees (only 9 percent which do not have works councils). On this evidence there is no disadvantage attaching to the absence of representative participation in the large majority of establishments.

For its part, profitability is distinctly lower in small and medium-sized establishments. ${ }^{34}$ (The profitability variable is subjective and is expressed in index form according to management's assessment of establishment earnings - where 1 is "very bad" and 5 denotes "very good"). At issue is the mechanism producing this result. The information in the third row of the table hints that rent-seeking in the form of higher wages might be the culprit, but not only are the (three 
performance) measures not commensurate but there are few indications of why this might be more pronounced in medium-sized than in larger-scale plants, although it might be the case that in larger plants more of the wage is taken out in fringes. ${ }^{35}$

The results for several measures of labor turnover contained in the next three columns of the table are notable for their general statistical insignificance. With the exception of reduced hires in larger plants with works councils (which may nevertheless flag classic insider behavior) there is no suggestion that this form of participation is associated with reduced turnover either in terms of quits or gross flows as might be suggested by collective voice considerations. That said, quits are inadequately measured since the 'departures' variable also includes dismissals, retirements, and deaths. Finally, if there is no evidence of any labor turnover benefit from works council presence then there is at least no immediate indication that innovative activity is retarded (though the profits result might hint at longer-term problems in this regard). That is to say, the association between works council presence and the introduction of new products or production processes is statistically insignificant throughout.

On balance, this evidence is by no means as prejudicial to works councils as that reported in the earlier econometric literature. By the same token, however, there is nothing in the data to suggest that smaller establishments suffer practically from a codetermination deficit and some evidence that they may be at a disadvantage (although in the absence of information on the joint surplus the welfare implications are necessarily opaque). The bottom line is that the economic justification for stimulating works council formation through legislation is unclear in respect of the large majority of workplaces. For larger establishments, it may be the case that legislation is either not a constraint or, more generously, that it may even be in basic accord with their organizational requirements. But even here the basis for a deepening in works council authority is opaque.

We conclude our discussion of the Hannover Firm Panel with some brief remarks on the recent analysis by Hübler and Jirjahn (2001), encountered earlier. Although the authors do not differentiate by establishment size, they pay especial attention to the issue of collective bargaining coverage. Their theoretical model is based on the idea that where a works council is embedded in an external collective bargaining framework (specifically, where the establishment is covered by a collective agreement) this will dissipate distributional conflict at the workplace and at the same time enhance any pro-productivity effect of the works council. Unlike the 
material contained in Table 5, works councils (and collective bargaining coverage) are endogenous in the model and handled via a double-selection methodology. The authors' results indicate higher productivity in works council regimes but only where the establishment is covered by a collective agreement. Similarly, wages are largely unaffected in covered works council regimes but higher in their uncovered counterparts. This may mean that our finding of higher wages in medium-sized establishments is picking up a plurality of uncovered works council establishments. But this is speculation. Hübler and Jirjahn do not disaggregate by establishment size and it is not clear that this would be feasible because of sample size considerations. Moreover, they do not report other evidence consistent with rent seeking; that is, establishment quasi-rents (measured by sales less raw materials and wages divided by employment) are seemingly not reduced in works council regimes without collective bargaining agreements. Interestingly, the authors' theoretical model does not accommodate the influence of union density as opposed to collective bargaining coverage. Finally, more important than the interaction between works council presence and collective bargaining coverage may be that between works councils and other forms of participation such as teamworking and profit sharing. ${ }^{36}$

Nevertheless, this study returns us to the theme of measurement. Although works council endogeneity per se may be less of an issue in large-scale data sets because of the number of detailed industry controls, there is a pronounced inferential problem in all cross-section exercises. Thus, for example, adverse performance might conceivably lead some firms to embrace works councils as a partial solution to the performance problem, in which case the finding of a negative coefficient estimate for the works council variable in cross section might even reflect reverse causation. The longitudinal capacity of the data set might suggest that we can use a fixed effects specification to control for differences in establishments. Although works council status can be ascertained in two of the four waves of the Hannover Firm Panel there are problems of sample attrition and also comparatively few cases of changes in works council status. This does not explain why Hübler and Jirjahn fail to experiment with a fixed-effects specification but it does indicate why this is not a fruitful exercise with prior disaggregation by establishment size. And even if it were possible to exploit the longitudinal capacity of the data set, there is the obvious point that panel estimation is not a panacea. Thus, if the characteristics of the firm (say the management ethos) change at the same time as does works council status, the 
advantage of a fixed effects specification necessarily evaporates. The same result obtains if movements in works council status in either direction are purposive and hence similarly signed. In short, this data set while offering real improvement over those used in previous studies still falls far short of the ideal. In what follows, we use a nationally representative data set that allows us to match establishments $a b$ initio and by obtaining a better fix on establishment heterogeneity allows improved estimates of works council impact on performance.

\section{Works Council Formation and Firm Performance: New Evidence from the IAB Establishment Panel}

Our survey of the extant empirical evidence revealed that all we know of works councils impact on (various dimensions of) firm performance has a basis in cross-section data, raising difficult problems of statistical inference. In an attempt to get a firmer grip on the causal effects of works councils, we next offer an alternative empirical strategy. The idea is to look at the effects of works council formation (rather than presence) on firm performance in the years after a works council has been formed by comparing establishments with new councils to matched establishments that have not so innovated.

This empirical strategy can only be undertaken using a data source that covers a large number of establishments over several years, with corresponding information on works council status and indicators of firm performance. To the best of our knowledge there is only one longitudinal data set in Germany that fulfils these rather demanding requirements. This is the IAB Establishment Panel of the Institute for Employment Research of the Federal Labor Service (Bundesantalt für Arbeit).

Each year since 1993 (1996), the IAB panel has surveyed several thousand establishments from all sectors of the economy in western (eastern) Germany. It is based on a stratified random sample - strata for 16 industries and 10 size classes - from the population of all local production units with at least one employee covered by social insurance. To correct for panel mortality, exits, and newly-founded units, the data are augmented regularly, producing an unbalanced panel. Participation of establishments is voluntary, but the response rates (which exceed 70 percent) are high compared with other non-official German firm panel studies. Data are collected in personal interviews with the owners or senior managers of the establishments by professional interviewers. The panel is created to serve the needs of the Federal Labor Service, so its focus is 
on employment related matters. ${ }^{37}$ Information on the works council status of establishments in western and eastern Germany is available for the 1996, 1998, and 2000 waves of the panel some results for 2000 were reported earlier in Table 3.

In order to investigate the impact of works council formation, as a first step we identified all those establishments without a works council in 1996. Of these plants, those subsequently reporting they had a works council in 1997 or 1998 that was still operational in 2000 form our group of 'treated' establishments. Establishments without a council over the entire sample period, 1996 to 2000, form our 'control' group. The former group comprises 31 establishments. ${ }^{38}$ Average employment in this group was 79.9 employees in June 1996 (the range being from 2 to 695 employees). Just one establishment had more than 300 employees, and only four had between 100 and 300 employees. Clearly, then, the large majority of innovating plants are small. ${ }^{39}$ The control group contains 1,513 establishments.

(Table 6 near here)

There are some marked differences between the treated and control groups as of 1996 when neither had works councils. Table 6 examines these differences for several workplace characteristics that have been found to be associated with works council presence. Thus, for example, it can be seen that establishments introducing a works council initially had a higher number of employees. This result is consistent with the view that employees in larger establishments are more likely to elect a works council because participation rights increase with establishment size. Innovating establishments also have, on average, higher shares of both bluecollar and shift workers and a lower proportion of female employees. These associations probably reflect different 'tastes' for collective representation among workers, as well as the special rights of works councils (e.g. in matters concerning the regulation of working time). Each of these differences in mean values is statistically different from zero at the 10 percent level or better. Furthermore, 16 percent of establishments introducing a works council, but only 8 percent of other establishments, were branch plants. This difference would be consistent with a demonstration effect emanating from the mother plants to its affiliate, but on this occasion the difference in means is not statistically significant at conventional levels. Finally, the profit situation in the two groups also does not differ significantly on average. ${ }^{40}$

The implication of the material in Table 6 is that the introduction of a works council is not a random occurrence. The different 'starting conditions' imply that observed differences over the 
sample period in the performance of establishments that did or did not introduce a works council cannot unambiguously be interpreted as a causal effect of a works council. If establishments from both groups differ significantly at a point in time when none of them (yet) had a works council, one would expect them also to display differences some years later - a conclusion that applies equally to those firms that introduced a works council had they in fact not done so. We simply have no data for the counterfactual situation (i.e. the 31 establishments failing to set up a works council). In sum, we cannot be sure that differences in the performance of establishments that introduced a works council vis-à-vis those that did not is caused by a works council.

This tension closely resembles that encountered in the evaluation of active labor market programs (or, indeed, any other form of treatment of units): If participants, or treated units, are not selected randomly from a population but are instead selected (or self-select) according to certain criteria, the effect of a treatment cannot be evaluated by comparing the average performance of the treated and the nontreated. Given that each unit (establishment, person, etc.) either participated or not, we have no information about its performance in the counterfactual situation. A promising way out is to construct a control group in such a way that every treated unit is matched to an untreated unit that is as similar as possible (ideally, identical) at a point prior to the treatment. Differences between the two groups (the treated and the matched nontreated) after the treatment can then be attributed to the treatment. ${ }^{41}$

To repeat, in our empirical investigation the treated group consists of the 31 establishments that introduced a works council in 1997 or 1998. For each of these firms we then searched for the most similar establishment from the universe of 1,513 establishments without a works council between 1996 and 2000. That is, we looked for a firm with the same (or very similar) number of employees, branch-plant status, share of blue-collar, shift, part-time and female workers, profit situation, region (western or eastern Germany), and industry affiliation. Technically this was achieved by first computing the so-called propensity score. This score is computed from a probit regression of a dummy variable indicating whether or not an establishment introduced a works council in 1997 or 1998 on all the relevant establishment characteristics mentioned above (as measured in 1996). A vector of variables was then assembled for each establishment consisting of the value of its propensity score, the number of its employees in 1996, and the location dummy for western/eastern Germany. Finally, for each of the 31 establishments that introduced a works council, the most similar nonintroducing plant - specifically, that establishment with the 
vector exhibiting the minimum Mahalanobis distance from the vector of the introducing establishment - was selected and matched to this unit. ${ }^{42}$ These matched nontreated establishments now form the control group.

(Table 7 near here)

Table 7 indicates that the matching was successful. A comparison of the mean values of variables in 1996 for establishments that subsequently introduced a works council and those who did not shows no statistically significant differences at conventional levels. In other words, both groups of establishments are very similar. Causal effects of introducing a works council can now be identified by comparing the mean values of performance indicators for the matched samples. Here we focus on the four performance indicators (measured over the entire period) that have been widely used in assessing the economic effects of industrial relations variables: ${ }^{43}$

- change in the quit rate, namely, the percentage point difference in the share of employees who voluntarily separated from their establishments in 1996 and 2000. Collective voice considerations and works councils' governance attributes would suggest that quits of dissatisfied employees should be reduced (and transformed into voice) after the formation of a works council;

- growth in labor productivity, proxied here by the percentage change in sales per employee. Both the broad collective voice model and the specific works council model of Freeman and Lazear (1995) would point to productivity increases due to works council cooperation effects. As we have seen, the selfsame argument was deployed by German federal government in advancing its proposals for reform of the Works Constitution Act;

- establishment growth, measured by the percentage change in the level of employment. If the introduction of a works council is generally beneficial for an establishment, as claimed by the German authorities, it should prosper and grow faster than other firms. If, however, works councils are not beneficial or if they pursue an insider-oriented policy, employment growth would be dampened or even reversed;

- change in the profit situation, indicated by a dummy variable that takes a value of one in case of a reduction in profitability between 1996 and 2000, zero otherwise. If the far-reaching rights of the works council are deployed for rent-seeking purposes, or if the operation of a works council is relatively expensive, company profits can be expected to fall following introduction of the entity. 
(Table 8 near here)

Mean values of these performance indicators for the innovating and noninnovating plants are reported in Table $8 .^{44}$ The prob-values uniformly indicate that the null-hypothesis of no differences in means between the two groups cannot be rejected. The suggestion is, then, that the introduction of a works council does not have a material causal effect on the mainstream indicators of firm performance considered here.

At one level, these results may look disappointing, but they are important for the debate over the new Works Constitution Act. It will be recalled that proponents of the new law have argued that substantial benefits will accrue from increasing works council penetration among smaller firms. We do not find any empirical evidence in favor of this position in our analysis of matched samples of (mostly) small firms. In particular, neither labor turnover nor labor productivity is improved by works council formation. These results must be set against the administrative costs of setting up and running a works council, all of which which have to be borne by the employer. ${ }^{45}$ From an economic perspective, then, serious doubts attach to the validity of the German government's claim that "[t]he benefit of an operational system of codetermination outweighs the additional expenses." 46

Given the regime shift, and the fact that our conclusions are based on a small sample of innovating establishments monitored over a short period of three to four years, this surely is not the last word in the controversy over works councils' impacts on establishment performance. However, the evidence we have assembled draws on a powerful new approach that has not been applied before in the investigation of works council impact of works councils, and has a basis in the best German data set.

\section{Interpretation}

The Works Constitution Act has once again been overhauled. The changes introduced are designed to make works council formation easier and to strengthen the hand of the worker side through more permanent works councilors and enhanced works council authority. The changes in the law follow on the heels of the report of a high-level commission of inquiry into the functioniong of the German codetermination system. Although this Kommission Mitbestimmung, or Codetermination Commisssion, eschewed making specific institutional recommendations, and accepted that the economic impact of the institution was unsettled, it nevertheless chose to 
emphasize the existence of a codetermination gap and further argued that the provision of worker representation could not be left to the vagaries of the market. In this light, the Commission can scarcely be surprised at the blunt legislative outcome.

The goal of the present treatment has been threefold: first, to describe the background to and nature of the legislative changes; second, to link the legislation to what we know of the economic impact of works councils; and third, given the limitations of extant analyses, to offer a new test procedure that gets around some of the problems encountered in the earlier empirical literature. In the first context, apart from demonstrating the tenuous link between economic analysis and policy formation - irrespective of the political complexion of the policy maker - we have had occasion to critique the conclusions of the expert commission of inquiry. In particular, we have argued that although the Commission's identification of a codetermination gap is descriptively correct (even understated), the facts of limited works council incidence and coverage should not be equated with a participation deficit. That is to say, German workers are much more likely to be covered by teamworking and be directly consulted by their employers than through reprentative participation. Although this leaves open the question of whether 'more' is sufficient, the point is that there are alternative means of engaging the workforce so that the focus on codetermination per se misses the wider participation picture.

Second, we interpreted the existing empirical evidence rather differently than did the Commission. Given that the costs of operating a works council are likely to be greater for smaller establishments, where works council coverage is currently patchy at best, we find it interesting that the Commission failed to report that it is precisely among such establishments that the evidence is least favorable to works councils. Larger plants seemingly find councils less of a constraint. Arguably, larger establishments might find it necessary to sent up institutions analogous to works councils in the absence of codetermination legislation, subject to rent seeking considerations. (Here the arguments of Hübler and Jirjahn, 2001, to the effect that such behavior is moderated in circumstances where the establishment is covered by a collective agreeement may have some force.) If the evidence for small plants is coupled with the facts on other forms of employee involvement practised in such establishments, then a case might even be made for exempting them from works council legislation rather than exposing them to more codetermination. 
Third, however, the limitations of the cross-section findings have to be borne in mind. We can never be sure that the links uncovered between works council presence and (adverse) establishment performance are causal. In recognition of this problem, we provided some new evidence on the effects of works council formation on several dimensions of establishment performance for otherwise matched samples of plants that did and did not introduce works councils, using longitudinal data for 1996-2000 from the IAB Establishment Panel. The procedure of matching plants on the basis of observables gives us more assurance that the observed differences between works council regimes are causal, even if we cannot rule out the influence of unobservable factors such as changes in management practices that not only influence performance but may also embrace representative participation. The latter observation further underscores the complementarity of case study work in this area.

The upshot of this procedure was that athough there were some large differences in the means of the (four) outcome variables between innovating establishments and their matched noninnovating counterparts, the standard deviations were such that none of these differences was statitistically significant at conventional levels. In short, we were unable to reject the null that the introduction of a works council had no effect on any of the measures of establishment performance examined.

At one level, the finding that plants introducing works councils do not record statistically significant differences in performance is at odds with the earlier, cross-section evidence because our innovating plants were predominantly small establishments with less than 100 employees. The caveat is of course that we are here examining works council formation rather than works council presence, so that any negative effects pointed to by past studies may not yet have had time to take root. On the other hand, the results are scarcely encouraging to those who have advocated changes in the law on economic grounds, most obviously because there is no real suggestion of any higher labor productivity or reductions in labor turnover accompanying works council formation.

Furthermore, it is not clear that works councils to be established in the wake of the new Works Constitution Act should be any more pro-productive than the (31) cases examined here. Indeed, the nature of the regime shift - namely, the greater facility in setting up works councils and the enhanced authority of the institution - might hint at less favorable outcomes. But the simple facts are that we do not know and in the absence of data permitting a natural experiment 
we are unlikely to be able to quantify the effects of the legislation with any precision. However, the growth in works councils can be monitored and establishment behavior tracked over succeeding waves of the IAB panel with a view to detecting structural breaks in key performance indicators. Recent EU legislation on national systems for informing and consulting workers serves to reinforce the importance of this follow-up inquiry. 


\section{ENDNOTES}

${ }^{1}$ See, for example, the deliberations of the Dunlop Commission (1994).

${ }^{2}$ See European Commission (1998).

${ }^{3}$ There is as yet no official translation of the new law. The Works Constitution Reform Act is published in Deutscher Bundestag, 14. Wahlperiode, Drucksache 14/5741 April 2, 2001. (This is available on the web at: www.bundestag.de). The new Act is published in the Federal Law Bulletin, Bundesgesetzblatt $B G B l . I S .1852$. (This is again available on the web at: www.bma.bund.de/download/gesetze/BetrVG.pdf.)

${ }^{4} \mathrm{~A}$ more detailed discussion of the evolution of the law is contained in Addison, Schnabel, and Wagner (2000a).

${ }^{5}$ We here abstract from changes in the law introduced in 1989 (Gesetz zur Änderung des Betriebsverfassungsgesetzes über Sprecherausschüsse der leitenden Angestellten und zur Sicherung der Montan-Mitbestimmung of December 1, 1998). The most important elements of this revision were the establishment of executive councils for senior executives and a modest extension of information and consultation rights for works councils proper in the event of the changes in technology.

${ }^{6}$ See, for example Streeck and Kluge (1999) and Frick, Kluge, and Streeck (1999).

${ }^{7}$ An English-language summary of report can be downloaded at www.mpi-fgkoeln.mpg.de/endbericht/inhalt_e.html

${ }^{8}$ See Aufbruch und Erneurung - Deutschlands Weg ins 21. Jahrhundert, Koalitionsvereinbarung zwischen der Sozialdemokratischen Partei Deutschlands und Bündnis 90/Die Grünen, Bonn, 20. Oktober 1998, Abschnitt I.8; www.bundesregierung.de:80/02/0203/020200/00.htm.

${ }^{9}$ See respectively, Deutscher Bundestag, 14. Wahlperiode, Drucksache 14/5741 vom 2.4.2001; Deutscher Bundestag, 14. Wahlperiode, Drucksache 14/5733 vom 3.4.2001; Deutscher Bundestag, 14. Wahlperiode, Drucksache 14/4764 vom 4.4.2001.

${ }^{10}$ Deutscher Bundestag, Ausschuss für Arbeit und Sozialordnung, 14. Wahlperiode, Drucksache 14/1512 vom 10.5.2001.

${ }^{11}$ For a comprehensive 226-page synopsis of the 1972 Act, the draft proposal of the government submitted on April 2, 2001, and the changes introduced into the legislation after the hearing before the Committee for Labor and Social Order, see www.bma.de. [select gesetze and then beschlüsse].

${ }^{12}$ See BMA-Pressestelle (2001); www.bma.bund.de/presse.asp?id=1436. 
${ }^{13}$ Begründung zum Entwurf eines Gesetzes zur Reform des Betriebsverfassungsgesetzes [Referentenentwurf] p. 23.)

${ }^{14}$ Deutscher Bundestag, 14. Wahlperiode, Drucksache 14/5741 of 2. 4. 2001, p. 32.

${ }^{15}$ Deutscher Bundestag, 14. Wahlperiode, Drucksache 14/5753 of 3. 4. 2001, p. 2.

${ }^{16}$ Ibid, p. 4.

${ }^{17}$ Deutscher Bundestag, 14. Wahlperiode, Drucksache 14/5764 of 4. 4. 2001, p.1f.

${ }^{18}$ Ibid., p. 4.

${ }^{19}$ The written statements can be found in Deutscher Bundestag, Ausschuss fur Arbeit und Sozialordnung, 14. Wahlperiode, Ausschussdrucksache 14/1512 of 10. 5. 2001, which is available at the web site: www.bundestag.de.

${ }^{20}$ Ibid., p. 82.

${ }^{21}$ Ibid., p. 96

${ }^{22}$ Ibid., p. 28

${ }^{23}$ Ibid., p. 111

${ }^{24}$ Ibid., p. 70.

${ }^{25}$ Ibid., at respectively pp. 133, 147, and 163.

${ }^{26}$ For broadly supportive information on works council frequency for a representative sample of approximately 1,000 industrial establishments in Lower Saxony, see below. See also Funder and Seitz (1997) and Dilger (1999) for corresponding data from the German machine tool industry. Results from a 1985 employment-based survey of more than 1,500 manufacturing establishments are contained in Frick and Sadowski (1995).

${ }^{27}$ The population of the Hannover Firm Panel is all manufacturing firms with at least 5 employees in the Land of Lower Saxony. The sample of establishments is stratified by firm size, with over-sampling of larger firms. The first wave of the panel contains information on 1,025 establishments. For information on this and the three remaining waves, see Brand, Carstensen, Gerlach, and Klodt (1996).

${ }^{28}$ Though Addison, Schabel, and Wagner (1997) find no evidence, contrary to Sadowski and Frick (1995), that the qualification structure of the workforce is associated with works council presence. 
${ }^{29}$ Though here we should again point out that the old Works Constitution Act placed minimal constraints on the formation of a works council if the workforce was desirous of one. But for instances of (illegal) employer interference with the election process, see Schumacher and Böhmer, 1995).

${ }^{30}$ The exception to this statement is provided by FitzRoy and Kraft's (1990) study of product market innovation, which finds that a composite works council variable - works council presence interacted with union density - is associated with reduced innovative activity. And, while reporting a positive association between works councils and an alternative innovation measure, Schnabel and Wagner (1994) do find that once union density attains a value of 50 percent the works council effect turns negative.

${ }^{31}$ But see the two-equation system deployed in FitzRoy and Kraft (1987) and the attempt to instrument the presence of the works council in Addison and Wagner (1997).

${ }^{32}$ Only Addison and Wagner (1997) offer a measure of the degree of participation or voice of the works council.

33 See also the estimations by Jirjahn (1998) and Hübler and Jirjahn (2001), who do not differentiate by establishment size.

${ }^{34}$ Dilger (1999) also identifies profitability-reducing effects of works councils in the NIFA panel, a large data set from the German machine tool industry.

${ }^{35}$ For the most thorough examination to date of the routes through which the remuneration package may be enhanced, see Addison, Schnabel, and Wagner (2001).

${ }^{36}$ In a follow-up study, FitzRoy and Kraft (1995) qualify their earlier harsh interpretation of works council impact on establishment performance. They now report that works councils in profit-sharing firms are positively associated with productivity; for their counterparts in non profit-sharing regimes, however, the works council effect is still negative and statistically significant.

${ }^{37}$ For more information on the IAB panel, which is financially supported by the European Social Fund, see Kölling (2000). We thank Holger Alda of the IAB for his help with the data. The data are confidential but not exclusive. Those interested in using them for scientific (noncommercial) research should contact the second author via e-mail: lutz.bellmann@iab.de

${ }^{38}$ Note that establishments in the nonprofit sector (public services, private households, etc.) are not included in our sample for obvious reasons. Furthermore, since establishments from banking and insurance do not report turnover they too are excluded, turnover per employee being our proxy for labor productivity.

${ }^{39}$ As a result, we cannot address differences in the impact of the works council across employment size intervals corresponding to different works council rights, which topic is potentially of great importance given the evidence summarized in section V. 
${ }^{40}$ The IAB Establishment Panel contains a subjective measure of profitability according to a fivepoint scale ranging from very good to very bad (using the grades common in German schools, namely, sehr gut, gut, befriedigend, ausreichend, and mangelhaft). The profit measure used in Tables 6 and 7 is a dummy variable that takes the value of one for establishments reporting a very good or good profit situation, zero otherwise.

${ }^{41}$ For a comprehensive discussion focusing on the evaluation of active labor market programs, see Heckman, LaLonde, and Smith (1999).

${ }^{42}$ For a theoretical discussion of the propensity-score-based Mahalanobis distance matching technique, see Rosenbaum and Rubin (1985). Matching was performed in Stata 7.0 using the psmatch command (Sianesi 2001). Note that an establishment that did not introduce a works council can be matched with more than one establishment that introduced a works council due to matching with replacement.

${ }^{43}$ See, inter al., Fernie and Metcalf (1995), Addison and Belfield (2001), and Cappelli and Neumark (2001).

${ }^{44}$ Because of missing values for sales and turnover, these two performance indicators could not be computed for all firms. As a result, the number of cases used in the calculations differ.

${ }^{45}$ Note that these administrative costs could well be too small to be reflected in the crude measure of (the change in) profitability.

${ }^{45}$ See note 13 supra. 


\section{REFERENCES}

Addison, John T., and Clive R. Belfield. 2001. "Updating the Determinants of Firm Performance: Estimation Using the 1998 UK Workplace Employee Relations Survey." British Journal of Industrial Relations 39 (September): 341-366.

Addison, John T., Kornelius Kraft, and Joachim Wagner. 1993. "German Works Councils and Firm Performance." In Employee Representation: Alternatives and Future Directions, ed. Bruce E. Kaufman and Morris M. Kleiner, pp. 305-336. Madison, Wisc.: Industrial Relations Research Association.

Addison, John T., Claus Schnabel, and Joachim Wagner. 1996. "German Works Councils, Profits and Innovation." Kyklos 49 (4): 555-582.

. 1997. "On the Determinants of Mandatory Works Councils in Germany." Industrial Relations 36 (October): 419-445.

. 1998. "Betriebsräte in der deutschen Industrie: Verbreitung, Bestimmungsgründe und Effekte." In Ökonomische Analysen betrieblicher Strukturen und Entwicklungen - Das Hannoveraner Firmenpanel, ed. Knut Gerlach, Olaf Hübler, and Wolfgang Meyer, pp. 59-87. Frankfurt and New York: Campus Verlag.

. 1999. "Verbreitung, Bestimmungsgründe und Auswirkungen von Betriebsräten: Empirische Befunde aus dem Hannoveraner Firmenpanel." In Die wirtschaftlichen Folgen der Mitbestimmung, ed. Bernd Frick, Norbert Kluge and Wolfgang Streeck, pp. 223-252. Frankfurt and New York: Campus Verlag.

. 2000a. "Nonunion Representation in Germany". In Nonunion Employee Representation History, Contemporary Practice, and Policy, ed. Bruce E. Kaufman and Daphne G. Taras, pp. 365-385. New York: M.E. Sharpe.

. 2000b. "Die mitbestimmungsfreie Zone aus ökonomischer Sicht." Hamburger Jahrbuch für Wirtschafts- und Gesellschaftspolitik 45: 277-292.

2001. "Works Councils in Germany: Their Effects on Establishment Performance." Oxford Economic Papers 53 (October): 659-694.

Addison, John T., and Joachim Wagner. 1997. "The Impact of German Works Councils on Profitability and Innovation: New Evidence from Micro Data." Jahrbücher für Nationalökonomie und Statistik 216 (1): 1-20.

BMA-Pressestelle. 2001. "Reform des Betriebsverfassungsgesetzes, Die Neuregelungen." Press Release of 22 June 2001. Berlin: Bundesministerium für Arbeit und Sozialordnung (BMA) 
Brand, Ruth, Vivian Carstensen, Knut Gerlach, and Thomas Klodt. "The Hannover Panel." Discussion Paper No. 2, University of Hannover, May.

Cappelli, Peter, and David Neumark. 2001. "Do 'High Performance' Work Practices Improve Establishment-Level Outcomes?" Industrial and Labor Relations Review 54 (July): 737-775.

Deutscher Gewerkschaftsbund [Bundesvorstand]. 1998. "Novellierungsvorschläge des DGB zum Betriebsverfassungsgesetz 1972." Düsseldorf: Deutscher Gewerkschaftsbund, Februar.

Dilger, Alexander. 1999. "Erträge bei differentzierter Betriebsbetrachtung - Erste Ergebnisse einer Untersuchung des NIFA-Panels." In Zur Entwicklung von Lohn und Beschäftigung auf der Basis von Betriebs- und Unternehmensdaten, ed. Lutz Bellmann, Susanne Kohaut, and Manfred Lahner. Nürnberg: Bundesanstalt für Arbeit.

Dunlop Commission. 1998. Commission on the Future of Worker-Management Relations. Fact Finding Report. Washington, D.C.: U.S. Department of Commerce/U.S. Department of Labor.

European Commission. 1998. "Proposal for a Council Directive Establishing a General Framework for Informing and Consulting Employees in the European Community," COM(98) 612 final. Brussels: Commission of the European Communities.

Fernie, Sue, and David Metcalf. 1995. "Participation, Contingent Pay, Representation and Workplace Performance: Evidence from Great Britain." British Journal of Industrial Relations 33 (September): 379-415.

FitzRoy, Felix, and Kornelius Kraft. 1985. "Unionization, Wages, and Efficiency: Theories and Evidence from the U.S. and West Gemany." Kyklos 38 (4): 537-554.

. 1987. "Efficiency and Internal Organization: Works Councils in West German Firms." Economica 54 (November): 493-504.

. 1990. "Innovation, Rent-Sharing and the Organization of Labor in the Federal Republic of Germany." Small Business Economics 2 (2): 95-103

. 1995. "On the Choice of Incentives in Firms." Journal of Economic Behavior and Organization 26 (January): 145-160.

Freeman, Richard B. and James L. Medoff. 1984. What Do Unions Do? New York: Basic Books.

Freeman, Richard B. and Lazear, Edward P. 1995. "An Economic Analysis of Works Councils." In Works Councils: Consultation, Representation, and Cooperation in Industrial Relation, ed. Joel Rogers and Wolfgang Streeck, pp. 27-50. Chicago, Ill.: University of Chicago Press. 
Frick, Bernd and Dieter Sadowski. 1995. "Works Councils, Unions, and Firm Performance." In Institutional Frameworks and Labor Market Performance, ed. Friedrich Buttler, Wolfgang Franz, Ronald Schettkat, and David Soskice., pp. 46-81. London and New York: Routledge.

Frick, Bernd, Norbert Kluge, and Wolfgang Streeck (eds.). 1999. Die wirtschaftlichen Folgen der Mitbestimmung. Frankfurt and New York: Campus Verlag.

Funder, Maria and Beate Seitz. 1997. "Unternehmens(re)organisation und industrielle Beziehungen in Maschinenbau." WSI Mitteilungen 50: 57-64.

Heckman, James J., Robert J. LaLonde, and Jeffrey A. Smith. 1999. "The Economics and Econometrics of Active Labor Market Programs." In Handbook of Labor Economics Volume 3A, ed. Orley C. Ashenfelter and David Card, pp. 1865-2097. Amsterdam: North-Holland.

Hübler, Olaf and Uwe Jirjahn. 2001. "Works Councils and Collective Bargaining in Germany: The Impact on Productivity and Wages." Discussion Paper No. 332, Institute for the Study of Labor (IZA), July.

Jirjahn, Uwe. 1998. Effizienzwirkungen von Erfolgsbeteiligung und Partizipation. Frankfurt/Main and New York: Campus Verlag.

Kölling, Arnd. 2000. "The IAB Establishment Panel." Schmollers Jahrbuch 120: 291-300.

Kommission Mitbestimmung. 1998. Mitbestimmung und neue Unternehmenskulturen - Bilanz und Perspektiven. Gütersloh: Verlag Bertelsmann Stiftung.

Kraft, Kornelius. 1985. "Exit and Voice in the Labor Market: An Empirical Study of Quits." Journal of Institutional and Theoretical Economics 142 (December): 697-715.

Rosenbaum, Paul R. and Donald B. Rubin. 1985. "Constructing a Control Group Using Multivariate Matched Sampling Methods That Incorporate the Propensity Score." The American Statistician 39 (February): 33-38.

Schnabel, Claus and Joachim Wagner. 1994. "Industrial Relations and Trade Union Effects on Innovation in Germany." Labour 8 (Autumn): 489-503.

Schumacher, Harald, and Reinhold Böhmer. 1995. "Betriebsräte - Dummes Zeug." Wirtschaftswoche No. 14, May 30, pp. 80-93.

Sianesi, Barbara. 2001. "Implementing Propensity Score Matching Estimators With Stata." Paper prepared for the U.K. Stata Users Group, VII Meeting, London, May.

Streeck, Wolfgang, and Norbert Kluge (eds.). 1999. Mitbestimmung in Deutschland - Tradition und Effizienz. Frankfurt and New York: Campus Verlag. 
Table 1

Membership of the Works Council by Establishment Size, Pre-existing and Current Legislation

Works Constitution Act No. of employees
No. of works councilors
Works Constitution Reform Act

No. of employees No. of works councilors

$\begin{array}{llll}5-20 & 1 & 5-20 & 1 \\ 21-50 & 3 & 21-50 & 3 \\ 51-150 & 5 & 51-100 & 5 \\ 151-300 & 7 & 101-200 & 7 \\ 301-600 & 9 & 201-400 & 11 \\ 601-1,000 & 11 & 401-700 & 13 \\ 1,001-2,000 & 15 & 701-1,000 & 15 \\ 2,001-3,000 & 19 & 1,001-1,500 & 19 \\ 3,001-4,000 & 23 & 1,501-2,000 & 21 \\ 4,001-5,000 & 27 & 2,001-2,500 & 23 \\ 5,001-7,000 & 29 & 2,501-3,000 & 25 \\ 7,001-9,000 & 31 & 3,001-3,500 & 27 \\ & & 3,501-4,000 & 29 \\ & & 4,001-4,500 & 31 \\ & 4,501-5,000 & 33 \\ & 5,001-6,000 & 35 \\ \text { In establishment with }>9,000 \text { employees the } & 6,001-7,000 & \\ \text { number of councilors is increased by 2 } & 7,001-9,000 & \\ \text { members for each incremental 3,000 } & & \\ \text { employees. } & \text { Unchanged } & \end{array}$

Note: The establishment size intervals pertain to number of employees with voting rights normally employed at the workplace. 
Table 2

Number of Works Council Members Released from their Work Duties by Establishment Size, Pre-existing and Current Legislation

Works Constitution Act

No. of employees
No. of paid, full-time works councilors
Works Constitution Reform Act

No. of employees No. of paid, full-time

$\begin{array}{ll}300-600 & 1 \\ 601-1,000 & 2 \\ 1,001-2,000 & 3 \\ 2,001-3,000 & 4 \\ 3,001-4,000 & 5 \\ 4,001-5,000 & 6 \\ 5,001-6,000 & 7 \\ 6,001-7,000 & 8 \\ 7,001-8,000 & 9 \\ 8,001-9,000 & 1 \\ 9,001-10,000 & 1\end{array}$

In establishments with $>10,000$ employees one further member of the works council is released for each incremental 2,000 employees.

$\begin{array}{lr}200-500 & 1 \\ 501-900 & 2 \\ 901-1,500 & 3 \\ 1,501-2,000 & 4 \\ 2,001-3,000 & 5 \\ 3,001-4.000 & 6 \\ 4,001-5,000 & 7 \\ 5,001-6,000 & 8 \\ 6,001-7,000 & 9 \\ 7,001-8,000 & 10 \\ 8,001-9,000 & 11 \\ 9,001-10,000 & 12\end{array}$

Unchanged

Note: The establishment size intervals refer to normal employment levels. 
Table 3

Incidence and Coverage of Works Councils in Germany

\begin{tabular}{|c|c|c|c|c|c|c|c|c|c|}
\hline \multirow{2}{*}{$\begin{array}{l}\text { Size inter } \\
\text { (no. of en }\end{array}$} & \multicolumn{3}{|c|}{ Western Germany } & \multicolumn{3}{|c|}{ Eastern Germany } & \multicolumn{3}{|c|}{ Germany } \\
\hline & \multicolumn{3}{|c|}{ Incidence $^{\mathrm{a}}$ Coverage $^{\mathrm{b}}$ Share $^{\mathrm{c}}$} & \multicolumn{3}{|c|}{ Incidence Coverage Share } & \multicolumn{3}{|c|}{ Incidence Coverage Share } \\
\hline $5-20$ & 9.3 & 10.5 & 25.7 & 7.8 & 9.8 & 27.8 & 9.1 & 10.4 & 26.0 \\
\hline $21-50$ & 29.9 & 31.5 & 14.8 & 29.9 & 30.8 & 18.4 & 29.9 & 31.3 & 15.4 \\
\hline $51-100$ & 52.9 & 53.4 & 11.4 & 51.2 & 51.3 & 13.1 & 52.6 & 53.0 & 11.7 \\
\hline $101-200$ & 68.6 & 69.5 & 11.5 & 69.1 & 69.7 & 11.7 & 68.7 & 69.5 & 11.6 \\
\hline $201-500$ & 81.4 & 82.6 & 14.1 & 76.2 & 77.4 & 12.8 & 80.6 & 81.8 & 13.9 \\
\hline $500>$ & 93.3 & 93.5 & 22.5 & 82.1 & 86.3 & 16.2 & 91.7 & 92.6 & 21.4 \\
\hline Average & 16.6 & 54.1 & & 15.4 & 47.1 & & 16.3 & 53.0 & \\
\hline
\end{tabular}

Notes: ${ }^{a}$ denotes the proportion of establishments in the class interval having works councils, ${ }^{b}$ the proportion of employees in the class interval employed in firms with works councils, and ${ }^{c}$ the employment share of the class interval. All data are weighted.

Source: IAB Establishment Panel, 2000. 
Table 4

Distribution of Teamworking, Consultation, and Profit Sharing by Works Council (WC) Presence and Establishment Size

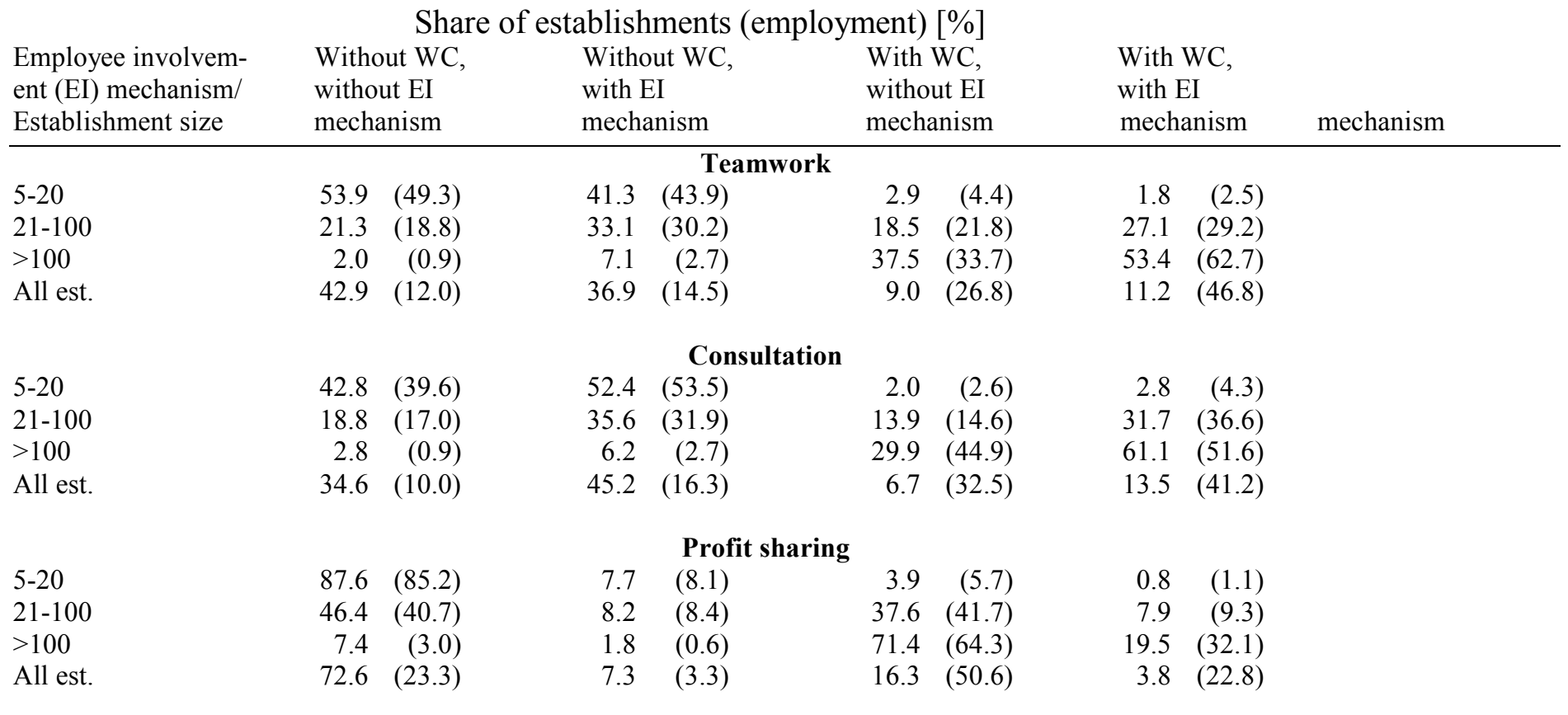

Note: Calculations based on weighted data.

Source: Hannover Firm Panel, Wave 1 (1994). 
Table 5

Effects of Work Councils on Various Indicators of Establishment Performance by Establishment Size Interval ${ }^{\mathrm{a}}$

$\begin{array}{lllll}\text { Indicator } & \begin{array}{l}\text { Estimation } \\ \text { procedure }\end{array} & 5-20 & 21-100 & \text { Establishment size interval } \\ & \text { OLS } & \text { none } & \text { none } & \text { positive* }^{\text {b }} \\ \text { Labor productivity } & \text { Ordered probit } & \text { negative** } & \text { negative** } & \text { none } \\ \text { Profitability } & \text { OLS } & \text { none } & \text { positive** } & \text { none } \\ \text { Wages } & \text { OLS } & \text { none } & \text { none } & \text { negative* } \\ \text { Hires } & \text { OLS } & \text { none } & \text { none } & \text { none } \\ \text { Departures } & \text { OLS } & \text { none } & \text { none } & \text { none } \\ \text { Labor fluctuation } & \text { Probit } & \text { none } & \text { none } & \text { none } \\ \text { Product innovation } & \text { Probit } & \text { none } & \text { none } & \text { none } \\ \text { Process innovation } & & & \end{array}$

Notes: ${ }^{\text {a }}$ Details of the regressions are available from the authors on request. Published results for all establishments and the 21-100 employee subsample are given in Addison, Schnabel, and Wagner (1998).

$\mathrm{b} * *, *$ denote statistical significance at the .05 and .10 levels, respectively.

Source: Addison, Schnabel, and Wagner (2000b). 
Table 6

Mean Values of Variables for Establishments Introducing/Not Introducing a Works Council, All Establishments $^{\mathrm{a}}$

\begin{tabular}{lccc}
\hline & $\begin{array}{l}\text { Establishments } \\
\text { introducing } \\
\text { a works council } \\
(\mathrm{n}=31)\end{array}$ & $\begin{array}{l}\text { Establishments } \\
\text { not introducing } \\
\text { a works council } \\
(\mathrm{n}=1,513)\end{array}$ & $\begin{array}{c}\text { Prob-value for } \mathrm{H}_{0}: \\
\text { diff. of means }=0^{\mathrm{b}}\end{array}$ \\
Variable & 79.90 & 34.48 & 0.066 \\
\hline Number of employees & 0.16 & 0.08 & 0.261 \\
Branch plant (dummy: 1 = yes) & 62.55 & 51.11 & 0.100 \\
Share of blue-collar workers (percent) & 22.16 & 7.76 & 0.037 \\
Share of shift workers (percent) & 14.86 & 14.80 & 0.990 \\
Share of part-time employees (percent) & 30.62 & 40.12 & 0.073 \\
Share of female employees (percent) & 0.42 & 0.33 & 0.337 \\
$\begin{array}{l}\text { Profit situation } \\
\text { (dummy: } 1 \text { = 'very good,' 'good') }\end{array}$ & & & \\
\hline
\end{tabular}

Notes: ${ }^{\text {a }}$ Data are for 1996 when establishments from both groups did not have a works council.

${ }^{\mathrm{b}}$ Two-sample t-test with unequal variances.

Source: Authors' own calculations from the IAB Establishment Panel. 
Table 7

Mean Values of Variables for Establishments Introducing/Not Introducing a Works Council, Matched Establishments $^{\mathrm{a}}$

\begin{tabular}{lccc}
\hline & $\begin{array}{l}\text { Establishments } \\
\text { introducing } \\
\text { a works council } \\
(\mathrm{n}=31)\end{array}$ & $\begin{array}{l}\text { Matched establishments } \\
\text { not introducing } \\
\text { a works council } \\
(\mathrm{n}=31)\end{array}$ & $\begin{array}{l}\text { Prob-value for } \mathrm{H}_{0} \text { : } \\
\text { diff. of means }=0^{\mathrm{b}}\end{array}$ \\
Variable & 79.90 & 75.75 & 0.893 \\
\hline Number of employees & 0.16 & 0.06 & 0.236 \\
Branch plant (dummy: 1 = yes) & 62.55 & 56.92 & 0.524 \\
Share of blue-collar workers (percent) & 22.16 & 24.39 & 0.809 \\
Share of shift workers (percent) & 14.86 & 11.4 & 0.547 \\
Share of part-time employees (percent) & 30.62 & 37.60 & 0.337 \\
Share of female employees (percent) & 0.42 & 0.52 & 0.453 \\
$\begin{array}{l}\text { Profit situation } \\
\text { (dummy: } 1 \text { = 'very good,' (good) }\end{array}$ & & & \\
\hline
\end{tabular}

Notes: ${ }^{a}$ Data are for 1996 when establishments in both groups did not have a works council. Matching was achieved using the propensity score plus the number of employees in 1996 and a dummy for eastern/western Germany using the PSMATCH procedure written by Barbara Sinesi (2001) for use with Stata 7.

${ }^{\mathrm{b}}$ Two-sample t-test with unequal variances.

Source: Authors' own calculations from the IAB Establishment Panel. 
Table 8

Mean Values of Performance Indicators in Establishments Introducing / Not Introducing a Works Council, Matched Establishments ${ }^{\mathrm{a}}$

Performance indicator

Establishments introducing a works council
Matched establishments not introducing a works council
Prob-value for $\mathrm{H}_{0}$ : diff. of means $=0^{b}$

Change in quit rate

(percentage points)

$$
\begin{gathered}
1.09 \\
(n=30)
\end{gathered}
$$

$-0.05$

$(\mathrm{n}=28)$

0.4109

Growth in sales per employee

$$
32.56
$$

8.87

$(\mathrm{n}=25)$

$(\mathrm{n}=25)$

Growth in number of employees

$$
6.83
$$

$(\mathrm{n}=31)$

16.81

(percent)

$$
0.35
$$

$(\mathrm{n}=31)$

Change in profit situation

$(\mathrm{n}=31)$

0.26

$(\mathrm{n}=31)$

(dummy: 1 = deterioration)

(n)

Notes: a Data are for 2000 compared with 1996 when establishments from both groups did not have a works council. Matching was achieved using the propensity score plus the number of employees in 1996 and a dummy for eastern/western Germany using the PSMATCH procedure written by Barbara Sianesi (2001) for use with Stata 7.

${ }^{\mathrm{b}}$ Two-sample t-test with unequal variances.

Source: Authors' own calculations from the IAB Establishment Panel. 


\section{IZA Discussion Papers}

\begin{tabular}{|c|c|c|c|c|}
\hline No. & Author(s) & Title & Area & Date \\
\hline 407 & $\begin{array}{l}\text { R. Schettkat } \\
\text { L. Yocarini }\end{array}$ & $\begin{array}{l}\text { Education Driving the Rise in Dutch Female } \\
\text { Employment: Explanations for the Increase in } \\
\text { Part-time Work and Female Employment in the } \\
\text { Netherlands; Contrasted with Germany }\end{array}$ & 5 & $12 / 01$ \\
\hline 408 & $\begin{array}{l}\text { H. N. Mocan } \\
\text { E. Tekin }\end{array}$ & $\begin{array}{l}\text { Nonprofit Sector and Part-Time Work: An } \\
\text { Analysis of Employer-Employee Matched Data } \\
\text { of Child Care Workers }\end{array}$ & 1 & $12 / 01$ \\
\hline 409 & $\begin{array}{l}\text { P. Apps } \\
\text { R. Rees }\end{array}$ & Fertility, Female Labor Supply and Public Policy & 6 & $12 / 01$ \\
\hline 410 & $\begin{array}{l}\text { H. Lehmann } \\
\text { J. Wadsworth }\end{array}$ & $\begin{array}{l}\text { Wage Arrears and the Distribution of Earnings in } \\
\text { Russia }\end{array}$ & 4 & $12 / 01$ \\
\hline 411 & S. Stillman & $\begin{array}{l}\text { The Response of Consumption in Russian } \\
\text { Households to Economic Shocks }\end{array}$ & 4 & $12 / 01$ \\
\hline 412 & $\begin{array}{l}\text { M. Barbie } \\
\text { M. Hagedorn } \\
\text { A. Kaul }\end{array}$ & $\begin{array}{l}\text { Government Debt as Insurance against } \\
\text { Macroeconomic Risk }\end{array}$ & 7 & $12 / 01$ \\
\hline 413 & $\begin{array}{l}\text { H. Bonin } \\
\text { R. Euwals }\end{array}$ & $\begin{array}{l}\text { Participation Behavior of East German Women } \\
\text { after German Unification }\end{array}$ & 1 & $12 / 01$ \\
\hline 414 & $\begin{array}{l}\text { A. Frederiksen } \\
\text { N. Westergaard- } \\
\text { Nielsen }\end{array}$ & Where Did They Go? & 1 & $01 / 02$ \\
\hline 415 & $\begin{array}{l}\text { M. Bertrand } \\
\text { F. Kramarz }\end{array}$ & $\begin{array}{l}\text { Does Entry Regulation Hinder Job Creation? } \\
\text { Evidence from the French Retail Industry }\end{array}$ & 6 & $01 / 02$ \\
\hline 416 & $\begin{array}{l}\text { B. Crépon } \\
\text { F. Kramarz }\end{array}$ & $\begin{array}{l}\text { Employed } 40 \text { Hours or Not-Employed 39: } \\
\text { Lessons from the } 1982 \text { Mandatory Reduction of } \\
\text { the Workweek }\end{array}$ & 6 & $01 / 02$ \\
\hline 417 & J. Wagner & $\begin{array}{l}\text { Taking a Second Chance: } \\
\text { Entrepreneurial Restarters in Germany }\end{array}$ & 1 & $01 / 02$ \\
\hline 418 & $\begin{array}{l}\text { M. Frölich } \\
\text { P. A. Puhani }\end{array}$ & $\begin{array}{l}\text { Immigration and Heterogeneous Labor in } \\
\text { Western Germany: A Labor Market } \\
\text { Classification Based on Nonparametric } \\
\text { Estimation }\end{array}$ & 2 & $01 / 02$ \\
\hline 419 & $\begin{array}{l}\text { P. Frijters } \\
\text { J. P. Haisken-DeNew } \\
\text { M. A. Shields }\end{array}$ & $\begin{array}{l}\text { The Value of Reunification in Germany: } \\
\text { An Analysis of Changes in Life Satisfaction }\end{array}$ & 6 & $01 / 02$ \\
\hline 420 & $\begin{array}{l}\text { A. Rosén } \\
\text { E. Wasmer }\end{array}$ & $\begin{array}{l}\text { Higher Education Levels, Firms' Outside Options } \\
\text { and the Wage Structure }\end{array}$ & 1 & $01 / 02$ \\
\hline 421 & P. Manzini & Divide et Impera: Negotiating with a Stakeholder & 6 & $02 / 02$ \\
\hline 422 & $\begin{array}{l}\text { J. T. Addison } \\
\text { L. Bellmann } \\
\text { C. Schnabel } \\
\text { J. Wagner }\end{array}$ & $\begin{array}{l}\text { The Long Awaited Reform of the German Works } \\
\text { Constitution Act }\end{array}$ & 6 & $02 / 02$ \\
\hline
\end{tabular}

An updated list of IZA Discussion Papers is available on the center's homepage www.iza.org. 